\title{
ANALISIS GANGGUAN 3 FASA PADA SALURAN TRANSMISI TERHADAP TRANSIENT STABILITY SISTEM MULTIMESIN MENGGUNAKAN METODE RUNGE-KUTTA ORDE 5
}

\begin{abstract}
Vina Aprilia ${ }^{1}$, Dikpride Despa ${ }^{2}$, Herri Gusmedi ${ }^{3}$, Lukmanul Hakim $^{4}$
${ }^{123}$ Jurusan Teknik Elektro Fakultas Teknik Universitas Lampung

${ }^{1}$ vinaaprilia05@ gmail.com, ${ }^{2}$ despa @ eng.unila.ac.id, ${ }^{3}$ herri.gusmedi @eng.unila.ac.id, ${ }^{4}$ plgsekip@eng.unila.ac.id Abstrak

Kontinuitas penyaluran daya listrik suatu sistem tenaga listrik harus terjaga keandalannya. Sistem yang andal hendaknya mampu menjaga kondisi dalam keadaan stabil bila terjadi gangguan. Untuk melihat kondisi tersebut, dapat dilakukan simulasi studi transient stability multimesin. Studi transient stability multimesin ini bertujuan menganalisis sistem tenaga listrik jika terjadi gangguan hubung singkat tiga fasa simetris terhadap setiap unit pembangkit di saluran transmisi bus beban. Gangguan di saluran transmisi ini mempengaruhi dari penentuan waktu pemutusan kritis yang cepat yaitu waktu kritis yang dibutuhkan generator sinkron untuk mempertahankan kondisi tetap dalam sinkronisasi. Tugas akhir ini, menentukan waktu pemutusan kritis selama kondisi transient dengan metode Runge-Kutta orde 5 sebagai metode tidak langsung. Metode Runge-Kutta orde 5 digunakan untuk menghitung penyelesaian numerik persamaan differensial nonlinear dengan studi kasus IEEE 9 bus 3 mesin. Hasil simulasi menunjukkan bahwa semua titik saluran transmisi pada bus beban yang mengalami gangguan memiliki waktu pemutusan kritis kurang dari 1 detik kecuali pada salah satu bus dan dua saluran dengan nilai 1.98-1.99 detik. Hal ini terjadi karena faktor pembebanan dan pengaruh besarnya reaktansi saluran di sistem tenaga tersebut. Faktor pembebanan yang relatif kecil memiliki waktu pemutusan kritis yang besar dari bus lainnya serta besarnya reaktansi saluran mempengaruhi transfer daya yang diterima menjadi kecil.
\end{abstract}

Kata kunci : Transient Stability, Sistem Multimesin, Metode Runge-Kutta Orde 5, IEEE 9 Bus 3 Mesin, Waktu Pemutusan Kritis Gangguan.

\begin{abstract}
Continuity of electrical power distribution in electric power system its reliability must be maintained. A reliable system should be able to maintain its stability in state of outages and fault condition. To obtain this conditions, transient stability multimachine study can be done. Transient stability multimachine study is aimed to analyse electrical power system when three phase short circuit symetrical to each generating unit the transmission line load bus. Fault in this transmission line is located based on the method to determine a fast critical clearing time, which is a critical time required by synchronous generator to mantain its condition remain in synchronism. This research, time of critical clearing time during transient condition will be determined by using Runge-Kutta Method $5^{\text {th }}$ Order as undirect method. Runge-Kutta Method $5^{\text {th }}$ Order is used to calculate numerical calculations of nonlinear differensial equations with IEEE 9 buses 3 machines. The results of this simulation show that all points in transmission line spesipically in load bus where the faulth occur have critical clearing time less than 1 second but it does not apply for one of the buses and two lines with $1.98-1.99$ second. It can be happened because of load factor and influence of reactance in power system lines. A relatively small factor have a great critical clearing time from other bus and the amount of lines reactance will affect received power transfer become smaller.
\end{abstract}

Keywords : Transient Stability, Multimachine System, Runge Kutta Method $5^{\text {th }}$ Order, IEEE 9 Buses 3 Machines, Critical Clearing Time (CCT) Fault.

\section{PENDAHULUAN}

Sistem kelistrikan memiliki beberapa pusat pembangkit yang saling terinterkoneksi meliputi pusat Pembangkit Listrik Tenaga Air (PLTA), Pembangkit Listrik Tenaga Uap (PLTU), Pembangkit Listrik Tenaga Gas (PLTG) dan pembangkit listrik lainnya. Di dalam keadaan sistem tenaga listrik yang saling terinterkoneksi seperti ini, maka tidak luput dari adanya gangguan pada sistem yang menyebabkan terganggunya aliran daya yang mengalir diberbagai bagian dari sistem. Gangguan yang sering terjadi berupa gangguan pada saluransaluran transmisi, dimana dapat menimbulkan kerusakan besar pada sistem khususnya dalam masalah peralihan (transient) yang akan tercakup dalam studi kestabilan. 
Kestabilan dimaksud sebagai langkah nyata dalam upaya analisis stabilitas sistem tenaga listrik agar pembangkit yang terganggu tidak terlepas dari sistem. Sistem yang baik adalah sistem yang memiliki stabilitas yang tinggi yaitu sistem dapat kembali bekerja secara normal setelah mengalami gangguan. Dan sebaliknya, ketidak-stabilan suatu sistem adalah kehilangan sinkronisasi dari sistem itu sehingga permasalahan stabilitas terkait dengan penilaian mesin sinkron setelah gangguan.

Untuk memudahkan analisis, permasalahan stabilitas secara umum dibagi dalam tiga katagori utama yaitu stabilitas keadaan tunak (steady state stability), stabilitas dinamik (dynamic stability) dan stabilitas peralihan (transient stability). Pada penelitian ini akan dilakukan studi transient stability yang bertujuan untuk menganalisa kestabilan yang dapat membantu menentukan setting waktu on/off relai proteksi dan waktu pemutusan kritis circuit breaker sehingga dapat meminimalisir kerusakan yang terjadi akibat gangguan pada saluran transmisi. Transient stability didasarkan pada aplikasi gangguan hubung singkat tiga fasa simetris pada sistem multimesin. Data dan metode yang digunakan merupakan data IEEE 9 bus 3 mesin dengan metode Runge-Kutta orde 5. Pada penelitian ini akan menentukan waktu pemutusan kritis yang tepat untuk mengantisipasi terjadinya ketidakstabilan sistem tenaga listrik.

\section{TINJAUAN PUSTAKA}

\section{A. Stabilitas Sistem Tenaga Listrik}

Keseimbangan daya antara kebutuhan beban dengan pembangkitan generator merupakan salah satu ukuran kestabilan operasi sistem tenaga listrik. Dalam buku Prabha Kundur, stabilitas sistem tenaga secara luas didefinisikan sebagai kemampuan dari suatu sistem tenaga untuk tetap dalam kondisi operasi seimbang saat terjadi kondisi tidak normal dan dapat mengembalikan ke kondisi seimbang setelah terjadi gangguan. ${ }^{[2]}$ Ketidakstabilan suatu sistem adalah kehilangan sinkron dari sistem, sehingga menimbulkan permasalahan dalam sistem jaringan yang menyebabkan terganggunya saluran transmisi dan kerusakan pada peralatan.

Untuk mempermudah analisis, masalah stabilitas secara umum dibagi dalam tiga katagori utama, yaitu :

1. Stabilitas keadaan tunak (steady state stability), kemampuan dari sistem tenaga untuk memperoleh kembali kesinkronan setelah terjadi gangguan kecil.

2. Stabilitas dinamik (dynamic stability), suatu kemampuan sistem tenaga untuk kembali ke titik keseimbangan yang baru setelah timbul gangguan yang relatif kecil secara tiba-tiba dalam waktu yang lama.

3. Stabilitas peralihan (transient stability), kemampuan sistem untuk mencapai kesinkronan setelah mengalami gangguan yang besar sehingga sistem kehilangan stabilitas akibat gangguan yang terjadi diatas kemampuan sistem.

\section{B. Kestabilan Sistem Multimesin : Representasi Klasik}

Ketika menganalisis stabilitas transient, maka perlu adanya penyederhanaan dengan asumsiasumsi di bawah ini :

1. Sebagai mesin sinkron atau serempak direpresentasikan sebagai sumber tegangan konstan di samping reaktansi transient sumbu langsung.

2. Aksi governor diabaikan dan daya masukan diasumsikan selalu konstan selama keseluruhan periode simulasi.

3. Semua beban diubah menjadi admitansi ke ground dan diasumsikan konstan.

4. Redaman atau daya asinkron diabaikan.

5. Sudut mekanik rotor setiap mesin berhimpit dengan sudut tegangan di samping reaktansi mesin. ${ }^{[3]}$

\section{Stabilitas Peralihan (Transient Stability)}

Masalah transient stability dapat lebih lanjut dibagi kedalam dua bagian yang meliputi, kestabilan ayunan pertama (first swing) dan kestabilan ayunan majemuk (multiswing. ${ }^{[4]}$ Untuk menganalisa transient stability, memiliki beberapa langkah yang harus dilakukan meliputi :

a. Menyelesaikan aliran daya untuk mendapatkan magnitude tegangan bus dan sudut fasa. Menghitung arus mesin sebelum gangguan dihitung dengan persamaan :

$I_{i}=\frac{S_{i}^{*}}{V_{i}^{*}}=\frac{P_{i}-j Q_{i}}{V_{i}^{*}}$,

b. Menghitung tegangan di samping reaktansi transient dengan mengabaikan resistansi jangkar generator yang ditentukan dari persamaan :

$E^{\prime}=V_{t}+j X_{d}^{\prime} I$.

c. Mengubah semua beban menjadi admitansi ekivalen dengan menggunakan persamaan :

$Y_{L}=\frac{S_{L}^{*}}{\left|V_{L}\right|^{2}}=\frac{P_{L}-j Q_{L}}{\left|V_{L}\right|^{2}}$

d. Menghitung matriks Ybus (matriks $n \times n$ ) pada kondisi sebelum gangguan (prefault), selama gangguan (faulted) dan setelah gangguan yang dihilangkan (postfault).

e. Menentukan matriks reduksi bus (Ybus) menggunakan Kron's Reduction dengan persamaan :

$Y_{b u s}^{\text {reduksi }}=Y_{m m}-Y_{n m}^{t} Y_{n n}^{-t} \cdot Y_{n m}$ 
f. Menentukan persamaan daya elektrik $P_{e i}$ sebelum gangguan antara daya masukan dan keluaran daya listrik :

$P_{e i}=\sum_{j=1}^{m}\left|E_{i}^{\prime}\right|\left|E_{j}^{\prime}\right|\left|Y_{i j}\right| \cos \left(\theta_{i j}-\delta_{i}+\right.$ $\left.\delta_{j}\right)$

g. Menyelesaikan kurva ayunan (swing curve) menggunakan metode Runga-Kutta Orde 5 dengan persamaan :

$$
\frac{H}{\pi f} \cdot \frac{d^{2} \delta}{d t^{2}}=P_{m}-P_{e} p u
$$

\section{Persamaan Ayunan (Swing Equation)}

Persamaan ayunan adalah persamaan yang mengatur gerakan rotor suatu mesin sinkron yang didasarkan pada prinsip dalam dinamika yang menyatakan :

"momen putar percepatan (accellarating torque) adalah hasil kali momen kelembaman (moment of inertia) rotor dan percepatan sudutnya". ${ }^{5]}$

$$
J \frac{d^{2} \theta_{m}}{d t^{2}}=T_{a}=T_{m}-T_{e} N m
$$

Persamaan ayunan menjadi :

$$
\frac{H}{\pi f} \frac{d^{2} \delta}{d t^{2}}=P_{m}-P_{e} \quad(\mathrm{pu})
$$

Pada persamaan di atas merupakan persamaan ayunan (swing equation) dimana persamaan dasar yang mengatur dinamika (gerak) perputaran mesin sinkron dalam kestabilan peralihan. Grafik dalam penyelesaian persamaan di atas disebut "Kurva Ayunan" (swing curve) mesin, dan dengan meneliti kurva ayunan semua mesin dalam sistem daya dapat diselesaikan dalam besaran $\delta$ terhadap waktu. Pada grafik di bawah ini, akan terlihat sebuah sistem stable atau unstable yang diperlihatkan pada gambar 1. (a) dan (b) :
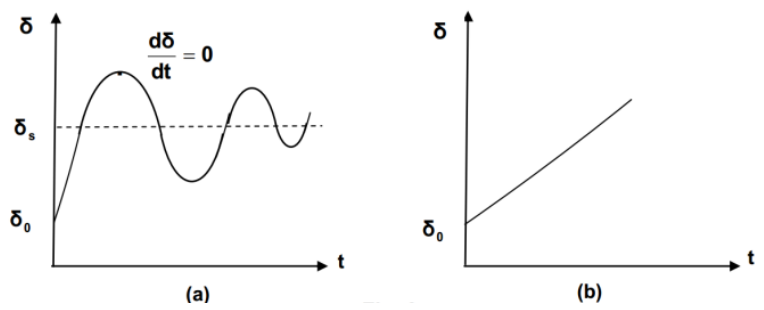

Gambar 1. Grafik $\delta$ terhadap $t$ untuk (a) sistem stable dan (b) unstable. ${ }^{[6]}$

\section{$E$. Metode Runge-Kutta Orde 5}

Metode Runge Kutta termasuk kedalam metode yang penyelesaiannya menggunakan penyelesaian numerik persamaan diferensial nonlinear. Metode Runge-Kutta merupakan salah satu metode numerik untuk memplot kurva ayunan sudut rotor. Dengan penyelesaian metode Runge-Kutta Orde 5 untuk menentukan harga $\delta$ dan $\omega$, terlebih dahulu harus menentukan harga-harga $k_{1}, k_{2}, k_{3}, k_{4}, k_{5}$ dan $k_{6}$ sebagai berikut : ${ }^{[7]}$

$$
k_{1}=f\left(\delta_{i} \omega_{i}\right) \Delta t=\omega_{i} \Delta t
$$

$$
\begin{aligned}
& l_{1}=g\left(\delta_{i} \omega_{i}\right) \Delta t=\frac{\pi f}{H}\left(P_{m}-P_{e}\right) \Delta t \\
& k_{2}=f\left(\delta_{i}+\frac{1}{4} k_{1}, \omega_{i}+\frac{1}{4} l_{1}\right) \Delta t \\
& =\left(w_{i}+\frac{1}{4} l_{1}\right) \Delta t \text {. (2.11) } \\
& l_{2}=g\left(\delta_{i}+\frac{1}{4} k_{1}, \omega_{i}+\frac{1}{4} l_{i}\right) \Delta t \\
& =\frac{\pi f}{H}\left(P_{m}-P_{e} \sin \left(\left(\delta_{i}+\frac{1}{4} k_{1}\right)\right) \Delta t\right. \\
& k_{3}=f\left(\delta_{i}+\frac{1}{4} k_{2}, \omega_{i}+\frac{1}{8} l_{1}+\frac{1}{8} l_{2}\right) \Delta t \\
& =\left(\omega_{i}+\frac{1}{8} l_{1}+\frac{1}{8} l_{2}\right) \Delta t \\
& l_{3}=g\left(\delta_{i}+\frac{1}{4} k_{2}, \omega_{i}+\frac{1}{8} l_{i}+\frac{1}{8} l_{2}\right) \Delta t \\
& =\frac{\pi f}{H}\left(P_{m}-P_{e} \sin \left(\left(\delta_{i}+\frac{1}{4} k_{2}\right)\right) \Delta t\right. \\
& k_{4}=f\left(\delta_{i}+\frac{1}{2} k_{3}, \omega_{i}-\frac{1}{2} l_{2}+l_{3}\right) \Delta t \\
& =\left(\omega_{i}-\frac{1}{2} l_{2}+l_{3}\right) \Delta t \\
& l_{4}=g\left(\delta_{i}+\frac{1}{2} k_{3}, \omega_{i}-\frac{1}{2} l_{2}+l_{3}\right) \Delta t \\
& =\frac{\pi f}{H}\left(P_{m}-P_{e} \sin \left(\left(\delta_{i}+\frac{1}{2} k_{3}\right)\right) \Delta t\right. \\
& k_{5}=f\left(\delta_{i}+\frac{3}{4} k_{4}, \omega_{i}+\frac{3}{16} l_{1}+\frac{9}{16} l_{4}\right) \Delta t \\
& =\left(\omega_{i}+\frac{3}{16} l_{1}+\frac{9}{16} l_{4}\right) \Delta t \\
& l_{5}=g\left(\delta_{i}+\frac{3}{4} k_{4}, \omega_{i}+\frac{3}{16} l_{1}+\frac{9}{16} l_{4}\right) \Delta t \\
& =\frac{\pi f}{H}\left(P_{m}-P_{e} \sin \left(\left(\delta_{i}+\frac{3}{4} k_{4}\right)\right) \Delta t\right. \\
& k_{6}=f\left(\delta_{i}+k_{5}, \omega_{i}-\frac{3}{7} l_{1}+\frac{2}{7} l_{2}+\frac{12}{7} l_{3}-\right. \\
& \left.\frac{12}{7} l_{4}+\frac{8}{7} l_{5}\right) \Delta t \\
& =\left(\omega_{i}-\frac{3}{7} l_{1}+\frac{2}{7} l_{2}+\frac{12}{7} l_{3}-\frac{12}{7} l_{4}+\right. \\
& \left.\frac{8}{7} l_{5}\right) \Delta t \\
& l_{6}=g\left(\delta_{i}+k_{5}, \omega_{i}-\frac{3}{7} l_{1}+\frac{2}{7} l_{2}+\frac{12}{7} l_{3}-\right. \\
& \left.\frac{12}{7}+\frac{8}{7} l_{5}\right) \Delta t=\frac{\pi f}{H}\left(P_{m}-P_{e} \sin \left(\delta_{i}+\right.\right.
\end{aligned}
$$$$
\left.\left.k_{5}\right)\right) \Delta t
$$

Sehingga harga $\delta$ dan $\omega$ dapat ditentukan dengan menggunakan persamaan :

$$
\begin{aligned}
& \delta_{i+1}=\delta_{i}+\frac{1}{90}\left(7 k_{1}+32 k_{3}+12 k_{4}+\right. \\
& \left.32 \boldsymbol{k}_{5}+\mathbf{7} \boldsymbol{k}_{6}\right) \\
& \omega_{i+1}=\omega_{i}+\frac{1}{90}\left(7 l_{1}+32 l_{3}+12 l_{4}+\right. \\
& \left.32 l_{5}+7 l_{6}\right)
\end{aligned}
$$

\section{F. Sistem Kelistrikan Model IEEE 9 Bus 3 Mesin}

Di bawah ini merupakan diagram segaris sistem kelistrikan data model IEEE 9 bus 3 mesin yang diperlihatkan pada gambar 2 . 


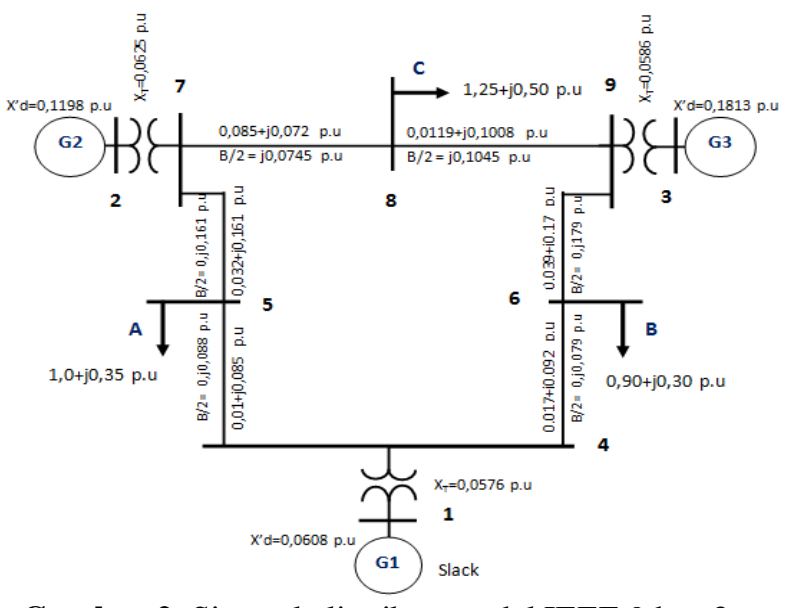

Gambar 2. Sistem kelistrikan model IEEE 9 bus 3 mesin. ${ }^{[8]}$

\section{METODE PENELITIAN}

Dalam penyusunan penelitian ini menggunakan diagram alir seperti pada gambar 3 di bawah ini.

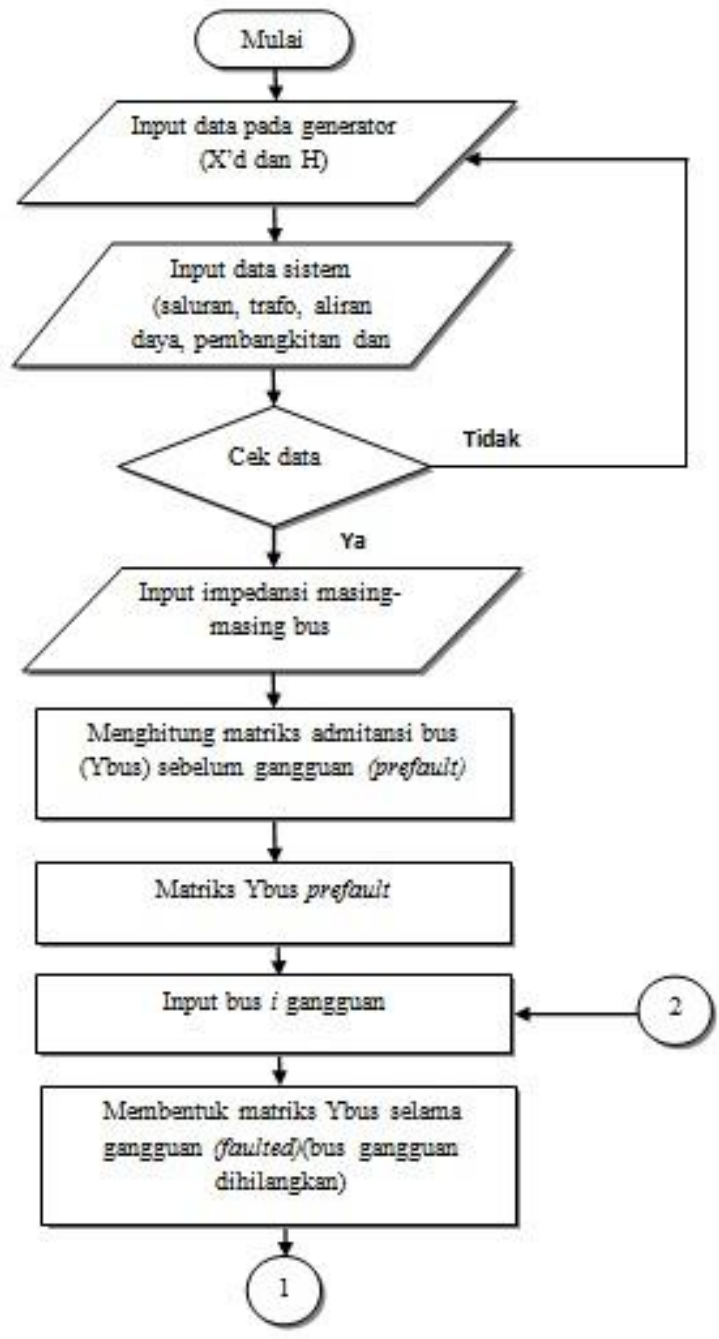

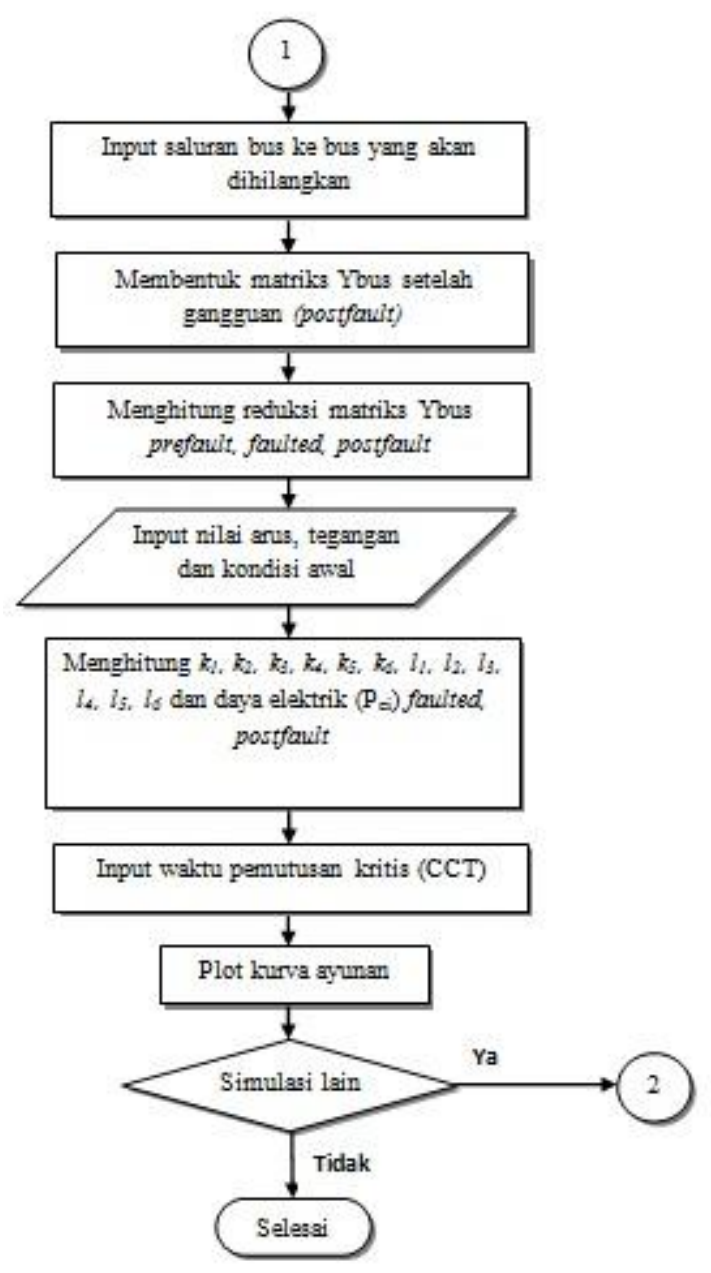

Gambar 3. Diagram alir penyelesaian kurva ayunan

\section{HASIL DAN PEMBAHASAN}

\section{A. Pemodelan Sistem}

Pemodelan sistem yang dianalisis untuk mendapatkan waktu pemutusan gangguan menggunakan sistem diagram segaris model IEEE 9 bus 3 mesin. Penelitian ini menggunakan perangkat lunak (software) sebagai program utama untuk mendapatkan grafik sudut rotor terhadap waktu dengan spesifikasi software MATLAB R2011a dan menggunakan jenis perangkat keras (hardware) pendukung berupa laptop dengan spesifikasi ASUS K43U Vision and Radeon HD6310M. Pada pemodelan sistem kelistrikan yang diperlihatkan pada Gambar 2., akan dilakukan simulasi kurva ayunan stabilitas peralihan meliputi hubung singkat tiga fasa yang terdapat di 12 titik gangguan.

\section{B. Hasil Simulasi Program}

Mendapatkan waktu pemutusan gangguan akibat hubung singkat tiga fasa pada saluran yang menghubungkan antar dua buah bus, maka disusunlah suatu program berbasis Matlab. Hasil simulasi dari 6 titik lokasi gangguan adalah sebagai berikut : 


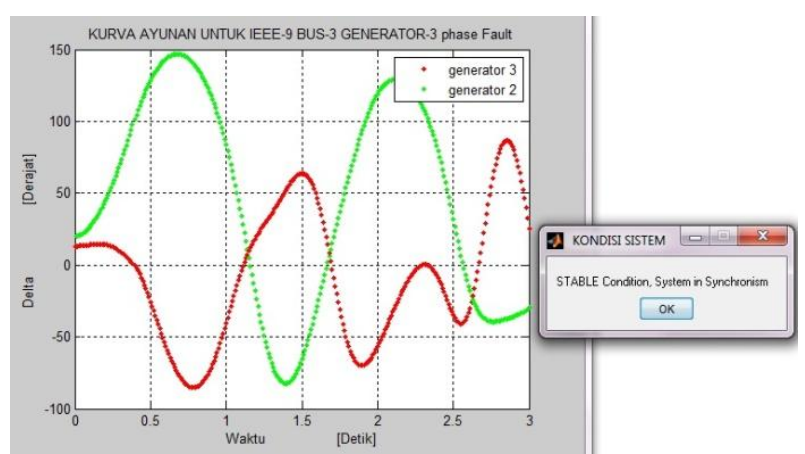

Gambar 4(a). Grafik hasil simulasi delta terhadap waktu di saluran 4-5 dekat bus 4, waktu pemutusan gangguan 0.39 detik (stabil).

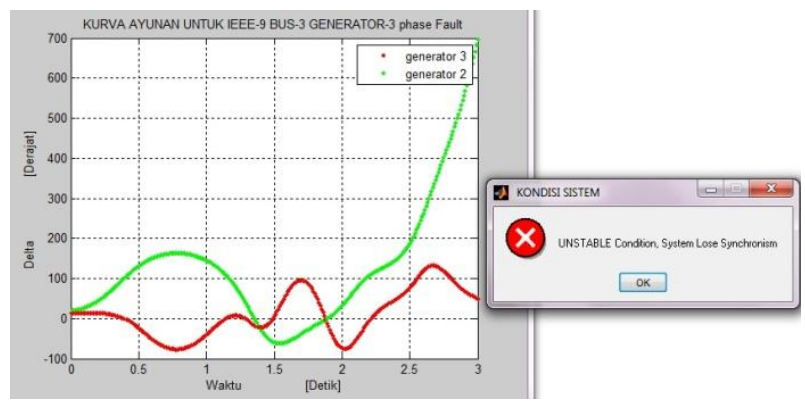

Gambar 4(b). Grafik hasil simulasi delta terhadap waktu di saluran 4-5 dekat bus 4, waktu pemutusan gangguan 0.40 detik (tidak stabil).

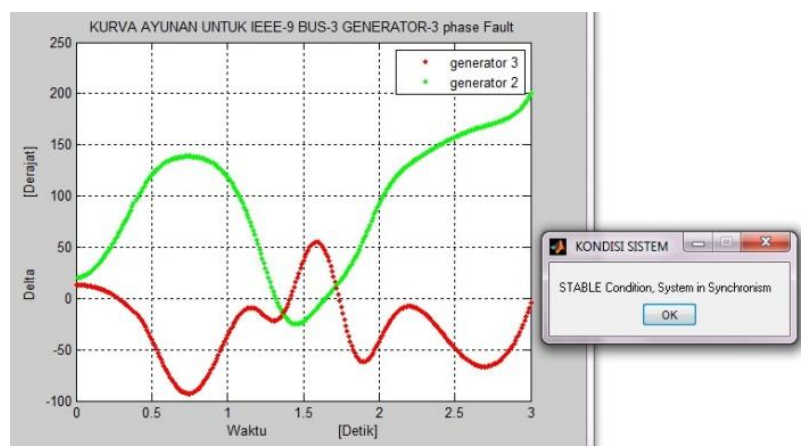

Gambar 5(a). Grafik hasil simulasi delta terhadap waktu di saluran 5-7 dekat bus 5, waktu pemutusan gangguan 0.39 detik (stabil).

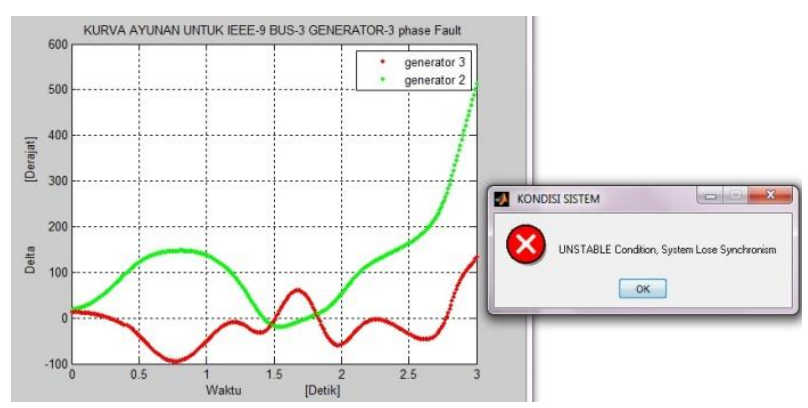

Gambar 5(b). Grafik hasil simulasi delta terhadap waktu di saluran 5-7 dekat bus 5, waktu pemutusan gangguan 0.40 detik (tidak stabil)

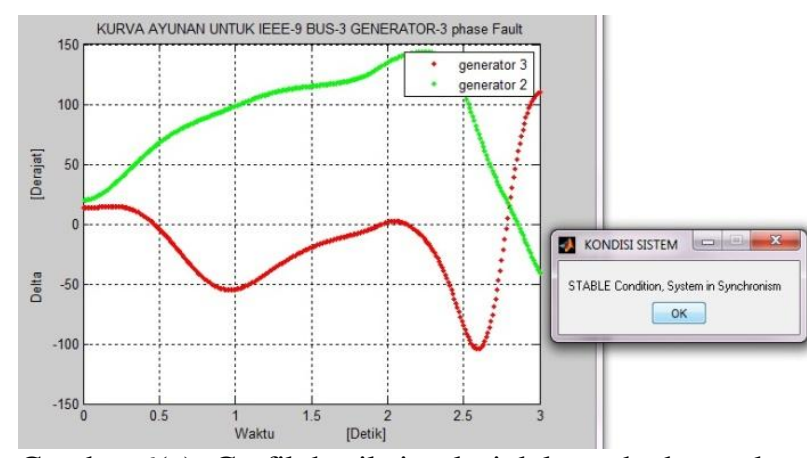

Gambar 6(a). Grafik hasil simulasi delta terhadap waktu di saluran 6-9 dekat bus 6, waktu pemutusan gangguan 1.97 detik (stabil).

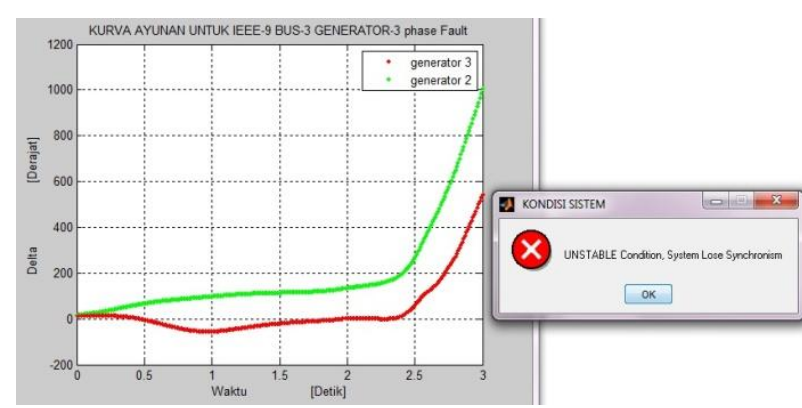

Gambar 6(b). Grafik hasil simulasi delta terhadap waktu di saluran 6-9 dekat bus 6, waktu pemutusan gangguan 1.98 detik (tidak stabil).

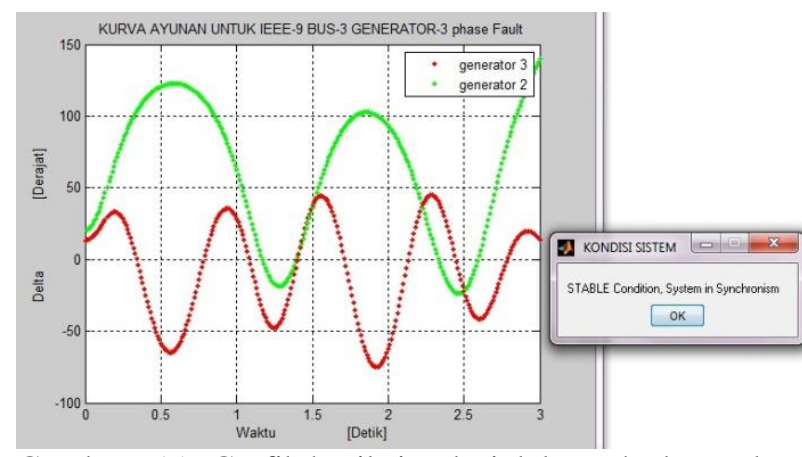

Gambar 7(a). Grafik hasil simulasi delta terhadap waktu di saluran 7-8 dekat bus 7, waktu pemutusan gangguan 0.14 detik (stabil).

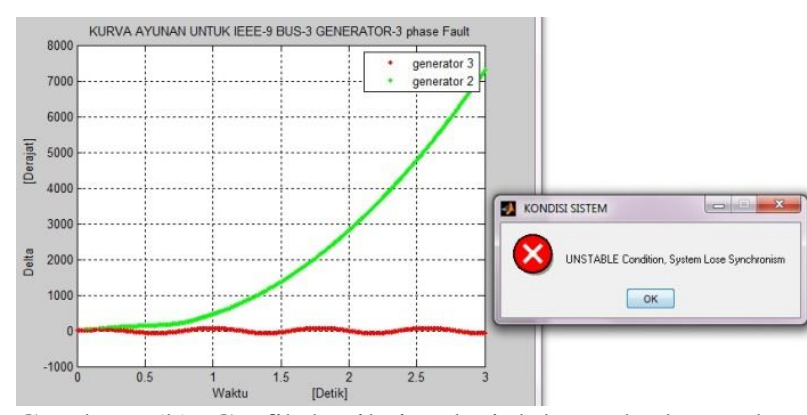

Gambar 7(b). Grafik hasil simulasi delta terhadap waktu di saluran 7-8 dekat bus 7, waktu pemutusan gangguan 0.15 detik (tidak stabil). 


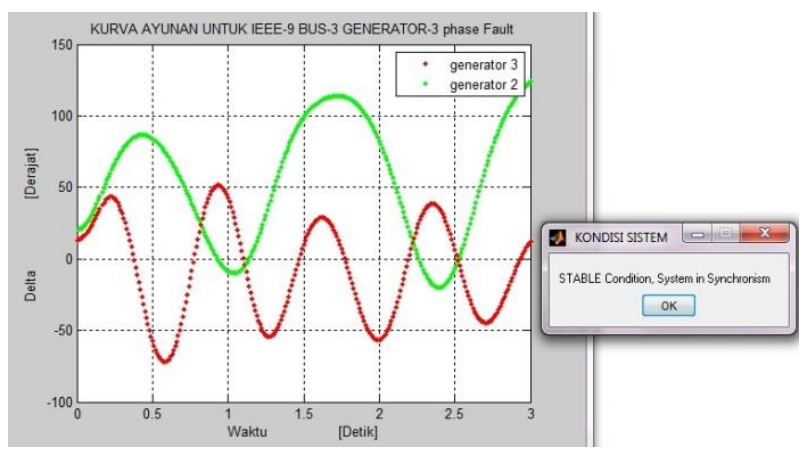

Gambar 8(a). Grafik hasil simulasi delta terhadap waktu di saluran 8-7 dekat bus 8 , waktu pemutusan gangguan 0.16 detik (stabil).

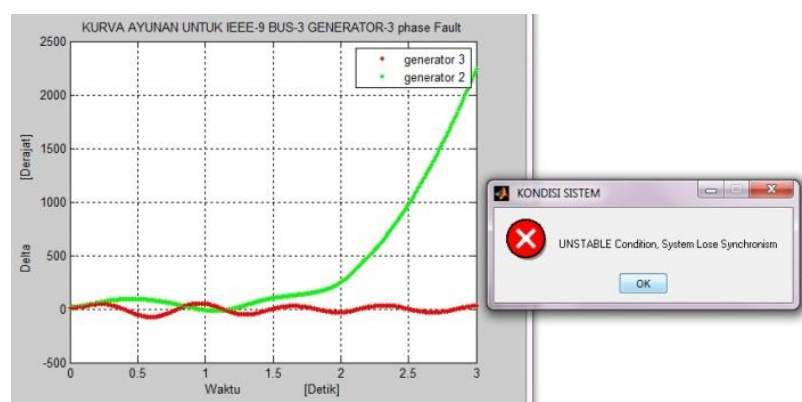

Gambar 8(b). Grafik hasil simulasi delta terhadap waktu di saluran 8-7 dekat bus 8 , waktu pemutusan gangguan 0.17 detik ( tidak stabil).

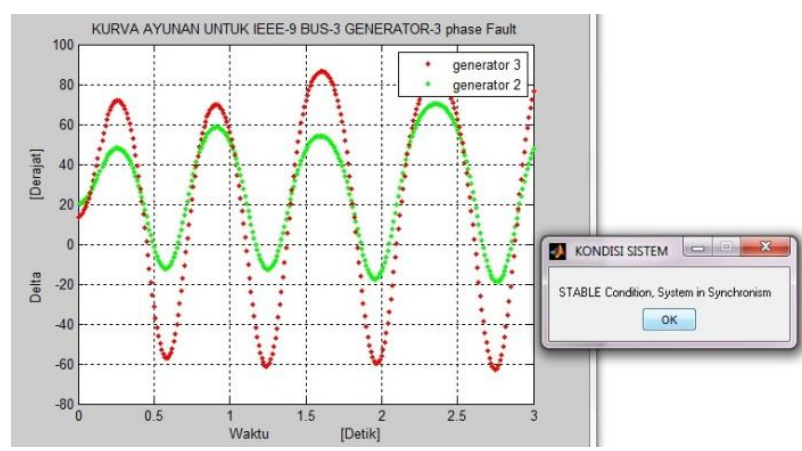

Gambar 9(a). Grafik hasil simulasi delta terhadap waktu di saluran 9-6 dekat bus 9, waktu pemutusan gangguan 0.15 detik (stabil).

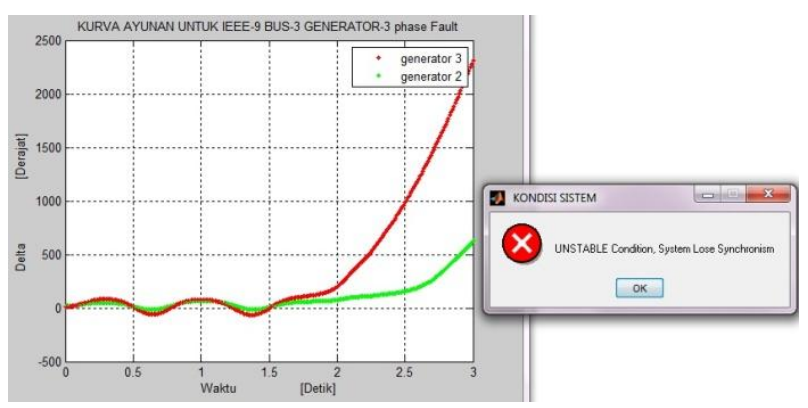

Gambar 9(b). Grafik hasil simulasi delta terhadap waktu di saluran 9-6 dekat bus 9, waktu pemutusan gangguan 0.16 detik (tidak stabil).

\section{Hasil Waktu Pemutusan Gangguan untuk Semua Titik Gangguan Saluran}

Hasil simulasi berupa waktu pemutusan kritis gangguan di setiap titik saluran transmisi bus beban pada model IEEE 9 bus 3 mesin diperlihatkan pada Tabel 1. berikut :

Tabel 1. Hasil Simulasi Sistem 9 Bus 3 Mesin

\begin{tabular}{|c|c|c|}
\hline $\begin{array}{c}\text { Saluran } \\
\text { Bus ke }\end{array}$ & $\begin{array}{c}\text { Lokasi } \\
\text { gangguan } \\
\text { dekat Bus }\end{array}$ & $\begin{array}{c}\text { Waktu } \\
\text { pemutusan kritis } \\
\text { gangguan (detik) }\end{array}$ \\
\hline $4-5$ & 4 & $0.39-0.40$ \\
\hline $4-6$ & 4 & $0.39-0.40$ \\
\hline $5-4$ & 5 & $0.43-0.44$ \\
\hline $5-7$ & 5 & $0.39-0.40$ \\
\hline $6-4$ & 6 & $1.98-1.99$ \\
\hline $6-9$ & 6 & $1.97-1.98$ \\
\hline $7-5$ & 7 & $0.14-0.15$ \\
\hline $7-8$ & 7 & $0.14-0.15$ \\
\hline $8-7$ & 8 & $0.16-0.17$ \\
\hline $8-9$ & 8 & $0.21-0.22$ \\
\hline $9-6$ & 9 & $0.15-0.16$ \\
\hline $9-8$ & 9 & $0.19-0.20$ \\
\hline
\end{tabular}

Tabel 1. terlihat bahwa hasil simulasi sistem IEEE 9 bus 3 mesin dengan lokasi gangguan saluran di bus beban yang berbeda memiliki waktu pemutusan gangguan tercepat adalah $0.14-0.15$ detik pada saluran 7-5 dan 7-8 dengan lokasi gangguan dekat bus 7 . Waktu pemutusan kritis gangguan pada bus-bus yang lebih dari 1 detik seperti saluran 6-4 dan 6-9 dengan lokasi gangguan dekat bus 6 yang terlihat pada tabel menunjukan bahwa cenderung memiliki nilai waktu pemutusan yang sangat besar, sehingga sistem masih tetap stabil selama gangguan dengan syarat tidak adanya mesin yang lepas selama periode waktu tertentu.

\section{Analisa Hasil Simulasi Kurva Ayunan}

Hasil simulasi berupa waktu pemutusan kritis gangguan untuk setiap titik pada saluran transmisi. Gangguan transient berupa gangguan hubung singkat tiga fasa simetris, dimana gangguan ini dipilih karena menghasilkan arus gangguan yang besar dibandingkan gangguan lain yang terjadi pada sistem. Waktu pemutusan gangguan untuk 12 titik di saluran bus diperlihatkan pada Tabel 1. Dari simulasi diperoleh bahwa gangguan dihilangkan pada waktu pemutusan yang berbeda pada masingmasing bus bebannya. Semua bus beban dalam sistem tenaga listrik model IEEE 9 bus 3 mesin 
memiliki waktu pemutusan dibawah 1 detik kecuali bus 6 .

Sistem tenaga masih dalam keadaan stabil bila kedua mesin mampu mempertahankan kestabilannya sebelum berakhirnya detik pertama. Pada bus-bus beban yang terganggu, mesin akan kehilangan kestabilannya ketika sudut rotor semakin besar pada periode waktu simulasi 3 detik. Ada beberapa faktor bahwa mesin akan kehilangan kestabilannya atau lepas dari sistem antara lain dapat dilihat dari lokasi gangguan, pembebanan, waktu pemutusan dan reaktansi saluran. Generator yang akan lepas dari sistem adalah generator yang dekat dengan saluran atau bus yang mengalami gangguan. Seperti pada saluran 9-6 dengan lokasi gangguan dekat bus 9. Dari sistem kelistrikan single diagram yang digambarkan 4.2. terlihat bahwa saluran 9-6 berada dekat dengan generator 3 dan berada jauh dari generator 2. Hal ini dapat mempengaruhi generator 3 terlebih dahulu lepas dari sistem ketika gangguan berada dekat bus 9, sedangkan generator 2 yang jauh dari bus 9 masih mempertahankan kestabilannya dan lepas dari sistem setelah lebih dari 2.5 detik periode simulasi.

Berikutnya, dari segi pembebanan dimana sangat mempengaruhi hasil waktu pemutusan gangguan. Bus yang terganggu mempunyai beban relatif kecil sehingga cenderung mempunyai waktu pemutusan yang besar. Pada model kelistrikan IEEE 9 Bus 3 Generator, terdapat beban di 3 bus yang meliputi, bus 5, 6 dan 8. Data beban pada bus 5, 6 dan 8 secara berurutan yaitu $125 \mathrm{MW}, 90 \mathrm{MW}$ dan $100 \mathrm{MW}$. Dalam hal ini, dapat dilihat bahwa bus 6 mempunyai data beban terkecil dengan 90 MW dibandingkan dengan data beban di bus 5 dan 8. Sehingga dengan data beban yang kecil mampu memiliki waktu pemutusan yang besar mencapai lebih dari 1 detik.

Faktor lainnya yaitu waktu pemutusan dan reaktansi saluran. Semakin lama waktu pemutusan gangguan maka semakin besar sudut rotornya. Mesin dikatakan tidak stabil dan lepas dari sistem ketika sudut rotor semakin besar di periode simulasi. Kemudian dari pengaruh besarnya reaktansi saluran, dimana seperti pada bus 6 yang memiliki data reaktansi saluran terbesar mencapai $0.1700 \mathrm{pu}$ dibandingkan dengan data reaktansi saluran di bus lainnya. Semakin besar reaktansi saluran maka semakin kecil transfer daya yang diterima, sehingga menyebabkan generator kehilangan kestabilannya dan mempunyai waktu pemutusan terbesar dari bus lainnya.

\section{KESIMPULAN DAN SARAN}

\subsection{Kesimpulan}

Berdasarkan pembahasan dan analisis yang telah dilakukan pada penelitian, dapat disimpulkan bahwa :
1. Metode Time Domain Simulation (TDS) dapat memecahkan permasalahan transient stability menggunakan penyelesaian numerik persamaan differensial nonlinear ( metode Runge-Kutta orde 5) melalui step by step untuk menghitung setiap mesin dari kurva ayunan.

2. Dari hasil simulasi, didapatkan bahwa semakin lama waktu pemutusan gangguan maka semakin besar sudut rotor yang dapat menyebabkan mesin kehilangan kestabilannya.

3. Dari 12 titik gangguan yang disimulasikan pada sistem IEEE 9 bus 3 mesin didapatkan waktu pemutusan gangguan tercepat saat $0.14-0.15$ detik pada SC bus 7 sedangkan SC bus 6 memiliki waktu pemutusan gangguan terlama (besar) lebih dari 1 detik.

4. Faktor yang mempengaruhi generator kehilangan kestabilannya atau lepas dari sistem meliputi lokasi gangguan, pembebanan, waktu pemutusan dan reaktansi saluran.

\subsection{Saran}

Berdasarkan hasil pembahasan dan kesimpulan diatas dapat disarankan bahwa :

1. Pada penelitian selanjutnya, sebaiknya menggunakan metode berorde lebih tinggi (metode multistep) dalam penyelesaian numerik persamaan differensial nonlinear untuk mendapatkan tingkat akurasi yang lebih baik pada hasil grafik kurva ayunan.

2. Menggunakan metode direct method (langsung) dalam menentukan waktu pemutusan kritis gangguan.

\section{REFERENSI}

[1] Rosalina, Analisa Kestabilan, FT UI: Bab 2, 2010.

[2] Prabha Kundur, Power System Stability and Control, McGraw-Hill, 1994.

[3] Cekmas Cekdin, Sistem Tenaga ListrikContoh Soal dan Penyelesaian Menggunakan Matlab, Yogyakarta: ANDI, 2007.

[4] James A.Pongtiku and Maickel Tuegeh, Analisa Stabilitas Transien Untuk Menentukan Waktu Pemutusan Kritis (Critical Clearing Time) Pada Jaringan Transmisi 70 kV PLTA Tanggari II-GI Sawangan Dengan Menggunakan Program Matlab, Manado: International Standard Serial Number (ISSN) : 2301-8402, 2014.

[5] William D.Stevenson, Analisis Sistem Tenaga Listrik Edisi Keempat, Jakarta: Erlangga, 1983.

[6] Dr. B. Kalyan Kumar, Power System Stability and Control, India: Department of Electrical 
Engineering, Indian Institute of Technology Madras.

[7] Hermawan, Analisa Pengaruh Pemasangan Kompensator Kapasitor Seri Terhadap Stabilitas Sistem, Semarang: Seminar Nasional Electrical. Informatics. And It's Education, 2009.

[8] Xi-Fan Wang.dkk, Modern Power Systems Analysis, New York: springer.com Library of Congress Control Number: 2008924670, 2008.

[9] Saffet Ayasun. dkk, A Sensitivity Approach For Computation of The Probability Density Function of Critical Clearing Time and Probability of Stability in Power System Transient Stability Analysis, USA: Applied Mathematics and Computation 176, 2005, 563-576,

[10] Mania Pavella. dkk, Transient Stability of Power Systems (A Unified Approach to Assessment and Control), London: University of Liege. Belglum, 1998.

[11] Aziz Al Haqim. M. Abdul. dkk, Perhitungan Critical Clearing Time Menggunakan Persamaan Simultan Berbasis Trajektori Kritis Tanpa Kontrol yang Terhubung Dengan Infinite Bus, Surabaya: Proceeding Seminar Tugas Akhir Elektro (TIS), 2014, 1-6.

[12] Steven C. Chapra. and Raymond P. Canale, Metode Numerik untuk Teknik, Jakarta: Universitas Indonesia (UI-Press), 2007.

[13] Heru Dibyo Laksono, Studi Kestabilan Transient Sistem Tenaga Listrik Multimesin (Model IEEE 9 Bus 3 Mesin), Padang: No. 30 Vol.1, ISSN: 0854-8471, 2008.

[14] Bessie M Baakanyang, Optimal Approach Towards Using Phasor Measurement (PMU) Data in Equal Area Criterion Based ystems for Power System Transient Stability Assessment, Jepang: PhD Thesis. Department of Electrical and Electronic Engineering. Graduate School of Engineering. Kyushu Institute of Technology, 2010.

[15] Dikpride Despa, Application of Phasor Measurement Unit (PMU) Data for Out Of Step Detection, Jepang: International Conference on Electrical Engineering, 2010.

[16] Heru Dibyo Laksono, Studi Stabilitas Peralihan Multimesin pada Sistem Tenaga Listrik dengan Metode Euler (Studi Kasus : PT. PLN P3B Sumatera), Padang: Vol. 19, ISSN: 0854-8471, 2012.

[17] Surya Atmaja, Perhitungan Critical Clearing Time dengan Menggunakan Metode Time Domain Simulation, Surabaya: Proseding Seminar Tugas Akhir Teknik Elektro FTI-ITS, 2012.

[18] Kiran Mishra and S. V Umredkar, Transient Stability Analysis of Multi Machine System,
India: International Journal of Science and Research (IJSR). India Online ISSN: 2319-7, 2013. 
